\title{
REIMAGINING LITERATURE IN THE ENGLISH LANGUAGE TEACHING CONTEXT IN THE RUSSIAN AND ARMENIAN HIGHER EDUCATION
}

Mariana S. Sargsyan, Yerevan State University, Armenia

Evgeniia V. Zimina, Kostroma State University, Russia, ezimina@rambler.ru

Original scientific paper

DOI: 10.31902/fIl.35.2021.7

\begin{abstract}
The paper aims to discuss the role of literature in teaching English as a foreign language. The interest in the topic is caused by the growing need to improve the content and approaches to teaching English as a foreign language at university departments that train teachers, linguists and philologists. The underlying argument is that the inclusion of literature in the language-teaching syllabus, the careful choice of the material and the appropriate means of its teaching may facilitate the assimilation of the language knowledge and enhance cultural knowledge. Further, the paper argues that the use of literature may be beneficial in terms of increasing the functional literacy of language learners. Translation and visualization are discussed as highly productive means of helping students fight the feeling of disorientation in text. To enhance the efficiency of the use of literature in class the authors offer a number of approaches to reading activities. The discussion and our observations can be helpful for all those specialists who face the dilemma of including literature in teaching English as a foreign language or are reconsidering their techniques of teaching literature by adapting it to the needs of learners.
\end{abstract}

Keywords: foreign language teaching, syllabus, fiction in the classroom, English literature, Scottish literature, functional illiteracy.

\section{Introduction}

In 2013, a student of Kostroma State University, a future teacher of English, applied for a summer course of contemporary English literature in a UK university. Her application was rejected, because, as it was explained in the letter, it was not clear why a teacher trainee needed to study literature. This reply was doubly sad: first, people who are engaged in teaching literature and disseminating knowledge about it do not see the use of literary texts in a language classroom. Besides, the 
reply came as a surprise, because the role of literature in Russian language classes at university has been unquestionable for many years. ${ }^{1}$

Generally, literature has been used in language teaching regularly since the beginning of the $20^{\text {th }}$ century (Maley, 2001). In the $1950 \mathrm{~s}-80 \mathrm{~s}$ in the Soviet Union ${ }^{2}$, literature was central to teaching English, especially to teacher trainees at universities, pedagogical colleges and teacher training institutions. However, the process was specific. On the one hand, it was believed that a teacher of foreign languages should have extensive knowledge of foreign culture, literature, history of the country where the language is spoken, and the history of literature in this country ${ }^{3}$. On the other hand, it was understood that a foreign language was unlikely to be used for speaking and face-to-face communication because personal contacts with foreigners were limited. It resulted in the thorough, detailed study of classical $19^{\text {th }}-20^{\text {th }}$ century English and American literature on all possible levels: not only the plot was discussed, but also lexical, grammatical, syntactical and stylistic features of the text were under study. Teachers often used their detailed lesson plans to accompany selected stories, chapters from larger texts or extracts, usually by B. Shaw, O. Wilde, W.S. Maugham, J. Galsworthy, Th. Dreiser, J.D. Salinger, E. Hemingway, A.J. Cronin, J. London, F.S. Fitzgerald, O' Henry and others. These texts were usually read in the original, which meant that students had to have an advanced level of English. As for beginners and intermediate-level students, the most popular teaching tool was the reader: an adapted or abridged book. ${ }^{4}$

\footnotetext{
${ }^{1}$ Although we may safely say that private tutors working with rich Russian families in the 19th century used French and German literary texts, of which there is numerous evidences by Russian classical writers who describe their childhood, e.g., Leo Tolstoy, Alexey Tolstoy, Sergey Aksakov and others.

${ }^{2}$ The discussion below along with observations are made regarding Kostroma State University (formerly Kostroma State Pedagogical Institute), Department of Romance-Germanic Languages specialized in training teachers of English and German/French; and Yerevan State University, English Philology Department, specialized in English language, philology and providing students with an additional qualification of teacher trainees.

${ }^{3}$ e.g., the UK and the USA. The Literature of Australia, Canada and New Zealand was studied less if at all, but not because it was considered unimportant, but because it was physically impossible to fit many writers in the curriculum.

${ }^{4}$ Beginners and pre-intermediate-level students often read adaptations, in which only the major plotline remained, and the text was re-written in a simpler language. More advanced students read abridged readers, in which only the most difficult passages were re-written or removed, and the most difficult grammar and vocabulary issues were explained in the detailed commentary.
} 
Such readers were based mostly on adventure and detective stories and novels by R. L. Stevenson, W. Scott, A. Christies, and A.C. Doyle, alongside with $\mathrm{O}$. Wilde's fairy tales or K. Mansfield's stories. Each reader was accompanied with a glossary, lesson plans, commentaries and other auxiliary materials, e.g., lists of discussion topics, scripts or suggestions for role-plays or games. Literary texts were also covered by so-called home-reading and individual-reading activities that were widely practiced and were mandatory for each term. Learners also had an obligatory course of the history of English literature which involved reading more complex texts, e.g., by G. Chaucer, W. Shakespeare, J. Milton, W. Scott, L. Byron, Ch. Dickens and other classical writers. ${ }^{5}$

At the end of the 80s, the political and economic reforms brought the first UK-published textbooks, e.g., Headway series by John and Liz Soars and numerous similar publications. These textbooks included different types of text. Teachers got access to other printed production: holiday brochures, magazines, leaflets. These resources were used in class as examples of 'real' English, and the share of literary texts in classroom materials declined significantly. At the same time, literature and text analysis remained part of the curriculum or were set as homework assignments ${ }^{6}$.

This picture seems almost idyllic; however, not everything is so perfect. The share of non-literary texts predominates and, as a result, as Calafato (2018) states, younger teachers of foreign languages in Russia feel less inclined to read themselves and encourage their students to do so. Here we should mention that although universities never gave up teaching literature completely, reading literary texts has become irregular and

\footnotetext{
${ }^{5}$ Textbooks for future language teachers and English learners used in Speaking classes often included texts, which served as a starting point for discussion (e.g., a textbook series by Professor Arakin, T. I. Matyushkina-Gerke, L.S. Golovchinskaya etc). In these textbooks along with classical pieces, you could find humorous stories (How We Kept Mother's Day by S. Leacock), stories about children or school (A Day's Wait by E. Hemingway) or social issues (extracts from Ragtime by E.L. Doctorow).

${ }^{6}$ For example, Kostroma State Pedagogical Institute (now Kostroma State University) had an activity called Individual Reading. Students were supposed to read a certain number of texts per term from a recommended list, which now included new names: William Golding, Flannery O'Connor, Margaret Mitchell, Ambrose Bierce, and even the bestsellers of the 90s, for example, by John Grisham. If students were eager to read, the tutor usually recommended only a few books and encouraged students to read the books of their own choice. Students and tutors often exchanged books they managed to find and often discussed them together.
} 
less systematic. For instance, the teaching of English at Yerevan State University takes place with the combination of locally published books containing literary texts and the UK or US published books. ${ }^{7}$

It should be mentioned that in the following chapters we will try to substantiate the role of literature and its relevance in teaching English as a foreign language. Further, we will refer to the problem of functional illiteracy in the foreign language-learning context and will further present a set of recommendations that can be applied in teaching English to university students who aspire to be teachers of English or master their language skills as future philologists. Our paper does not cover the situation in an EFL classroom at schools and in those universities that do not specialise in languages, linguistics and philology.

\section{Revising the Role of Literature}

If we refer to the primary aim of learning a foreign language, i.e., learning to communicate effectively in a culturally appropriate manner, it seems expedient to base the teaching on more practical and less sophisticated material. Dialogues, films, newspaper articles, leaflets and other similar material will surely help students develop adequate language skills and improve adequate communication skills. However, we assume that the language departments should in no way limit their syllabi to teaching the basic skills or providing theoretical knowledge on language-related issues. Teaching at a university irrespective of the specialization should be aimed at developing a whole range of skills that are essential for individual research and training highly qualified specialists. Research-based teaching has become one of the relevant approaches that universities are encouraged to practice at all levels of education. In this respect, it seems natural that language teaching also should be combined with as many aspects as possible, by enabling students to increase the range of their knowledge and acquire adequate skills for individual research.

If we consider the issue of teaching a foreign language to teacher trainees or linguists(philologist) from this perspective, it becomes clear

\footnotetext{
7 There is no consensus over the status of locally published books. There are ongoing discussions whether literature should be given too much attention to in language teaching, the basic argument being that the vocabulary is not practical and fails to provide students with practical skills for live communication with a foreigner or learn to distinguish between every day, formal and literary levels of language. Apart from this, extensive reading has become an optional activity depending on the teacher's choice.
} 
that literature is a crucial means that may contribute to implementing a research-based approach.

The first signs of the revived interest in literature as a teaching method were seen at the beginning of the 2000s, and not in Russia alone. Carter and Long in the UK (1991), Kennedy and Falvey (1999) in Hong Kong, Inan and Yüksel (2013) in Turkey Zhuvikina and Feoktistova (2011) in Russia and many other researchers have stressed the importance of reading fiction in developing language skills.

Opponents of this belief stress that the language of literary fiction differs from spoken English and is described as deviant (Gilroy and Parkinson, 1996). However, our classroom observations have shown that the language used in authentic EFL textbooks also differs considerably from the way native speakers normally speak. Besides, many successful textbook series have been aligned with the CEFR, which led to their simplification ${ }^{8}$. The latter, undoubtedly, leads to the increase in sales, which is profitable for publishers, but hardly be regarded as beneficial for learners: many of our students admit that when they start reading authentic texts (be it fiction, poetry, newspaper articles, or Internet resources), they see an immense gap between 'real' English and 'textbook' English.

In this situation, the importance of authentic fiction is difficult to overestimate, although it would be erroneous to think that literature has won a stable place in an EFL classroom. The reasons why teachers are reluctant to use literary texts in class vary. Calafato (2018) suggests that teachers in Russia, and this can be applied to the case of Armenia, are pressed for time. Indeed, time restrictions pose a serious problem, associated mainly with secondary schools. However, both Russian and Armenian universities are gradually developing a similar tendency. Particularly, teacher training specializations face the reduction in the number of hours allocated for major subjects (in our case, the language) in favour of Pedagogy and related subjects, with a possible danger that soon teachers will understand more about teaching techniques than the subject they are supposed to teach.

Despite the new challenges, changes in the curriculum and new administrative requirements, literature has not lost its position in

\footnotetext{
${ }^{8}$ The first editions of Headway Advanced by Oxford University Press included more complicated and sophisticated materials than later editions. Some advanced textbooks, suitable for advanced university students, i.e. English Panorama by Cambridge University Press or Upgrade your English (by Anita Debska, Oxford University Press) are not published any longer.
} 
training language teachers and has gained a reputation of an effective tool for language learning 9 .

Kostroma State University has designed a simple questionnaire for its teaching staff and for those of universities of Moscow Region (Kolomna) and St. Petersburg. The questionnaire, answered by 26 respondents, included the following questions:

1. Rate the use of literary texts in ELT as 1-5 from very low to very high;

2. Rate the response of your students to the introduction of literary texts in your EL classroom as 1-5 from very unenthusiastic to very enthusiastic;

3. An open-end question: Enumerate the advantages and disadvantages in the FL classroom;

4. An open-end question: Enumerate your favourite books you use in class.

The first two questions were answered predictably: 24 of the respondents estimated the role of literary texts as very high, 2 as moderate (the teachers' age was below 30).

The students' reaction was described as moderate by 18 respondents, as unenthusiastic - by 2 respondents, very unenthusiastic -1 respondent, enthusiastic -5 respondents.

The answers to the third question varied considerably starting from the advantages mentioned in our paper up to purely organisational advantages ("You can use the lesson plan again and again", "You can keep the students busy for a long time"), which proves Calafato's (2018) statement only partly, as there were only four respondents who mentioned time management.

The last question was the least representative as the respondents enumerated such a variety of reading material that we have failed to see common trends in the choice of genres and authors. The only conclusion to be made from this list is that the choice of reading texts depends entirely on the teacher.

One may dispute the necessity of resorting to traditional methods in the contemporary situation, especially in the pandemic era when we both teachers and learners are forced to use technology more often

\footnotetext{
${ }^{9}$ This reputation is promoted by a variety of activities organised by the Cultural Section of the British Embassy in Russia. Among them are British literature seminars with contemporary British authors in Yasnaya Polyana, the memorial house of Leo Tolstoy.
} 
than usual and adapt materials for remote learning. Reading materials require special adaptation. But this is precisely the point. Our own experience shows that the more students are involved in new, computer-based activities, the higher the level of their emotional burnout and the lower the understanding of the material under study. Now, when the lockdown in Russia is over, our students themselves report that they have noticed that reading fiction helped them to relax after hours in front of the screen. It helped to overcome the feeling of loneliness and isolation. Those students who preferred reading and writing poetry as a way to cope with the pandemic-related stress, report the improvement of their vocabularies.

On the other hand, traditional methods of teaching language with the help of fiction do not deny the opportunity of adapting these methods for Internet-based learning if, for some reason, the teacher does not want or cannot have face-to-face classes.

Therefore, we genuinely believe that reading based only on nonfiction texts deprives learners from the connections with the cultural heritage of the mankind. It is especially dangerous nowadays when good books are banned by those who have not read them or who have failed to interpret the meaning of the book; when the decision to ban is based on a couple of formal criteria (e.g., obsolete vocabulary) and disregards the moral and the cultural value of the text.

Therefore, literature is now seen as a tool to overcome obstacles we are planning to describe below.

\section{The Choice of Reading Materials}

To use literature in the FL classroom to the best advantage requires a thorough revision of methods. The study of literature should be aimed at providing students with knowledge in literature, develop their imagination and help them establish associations with reality. In this respect, the material should suit the purpose, in the meanwhile in the choice of the material teachers should be highly cautious.

A typical student of the Foreign Languages Department at Kostroma State University and Yerevan State University is a female aged 18-22. Male students find a career in philology or teaching less attractive; therefore, a group of 20 students usually includes from 0 to 4 males. It does not mean, however, that a typical book to read in class will be a love story or any other genre of stereotypically female literature.

Apart from the textbook material, teachers are relatively free in their choice of reading materials, although the syllabi usually include reading lists. However, the choice of books is determined by the 
teacher's understanding of how a particular book will improve students' language skills. Therefore, teachers may use one of the following approaches or combine them, if necessary.

1. Linguistic approach involves the use of complex tasks aimed to analyse the vocabulary and grammar of the text, its structure and the stylistic devices used by the author to convey his/her ideas. Bekisheva and Gasparyan (2014) indicate that tasks may vary from gap filling/matching etc., to writing essays on the text under study, arranging role-plays and summarising the content.

2. Cultural approach focuses on the culture of the period when the text was created, the author's philosophy, politics and ideas. Ainy (2017) states that under this approach, students understand the text better. Savvidou (2004), on the other hand, argues that learners do not practice their speaking skills enough.

3. Personal approach is based on students' own experience and opinions - they may discuss the language, the author's ideas, the message of the text; in this way their own opinion of the text is formed (Bloemert, Jansen, van de Grift, 2016).

Our own experience shows that each of these approaches has its advantages and drawbacks. The most practical solution would involve a combination of those. The following factors may also influence the teaching strategies.

1. Students' language level.

If students have limited vocabulary and poor or basic grammar, the linguistic approach contributes to their improvement. Later, elements of other approaches are added to motivate students further.

2. Character traits.

Being shy is not the trait of character a future teacher should have. However, some students tend to be shy if they are aware that their level is lower than that of other students. The linguistic approach can serve as a bridge to the personal approach if the tutor combines formal and communicative tasks.

\section{Students' creativity level.}

If there are creative and enthusiastic students in the group (and there are always are), the teacher may capitalise on their creativity and resort to the personal and cultural approaches, while the linguistic approach is added later to brush up grammar mistakes.

4. Students' level of background knowledge.

Some students with little background knowledge are quite content with doing formal vocabulary and grammar exercises. By introducing the cultural approach gradually, the teacher expands 
students' background knowledge, which would later help them express their own opinion more freely and make informed conclusions.

Student groups, however, are hardly ever homogeneous. That is why the teacher may prefer to combine approaches. In this case, a short story is a preferable type of text. Students may start with finding information about the author and the problems of the period, then work on vocabulary and discuss "deviant" grammar, and then proceed to discuss questions related to the author's intentions and their interpretations of the story.

Alternatively, the teacher may use the language approach and a short story one week, and the combination of the cultural and language approaches and a poem next week. Students who like intellectual challenges will enjoy puzzles hidden in Carson Ciaran's Dresden or Sarah Perry's The Essex Serpent.

Here we have come to another important issue - text selection. How old should the text be? Zagryadskaya (2017) emphasizes the importance of contemporary texts as the language and the problems raised in these texts are closer to students. She, however, does not exclude the possibility of using older texts.

Our own experience shows that students are not necessarily bored by classical literature ${ }^{10}$. On the other hand, world news can inspire students to read a contemporary text ${ }^{11}$. It follows that it is extremely important for the teacher to be flexible. Obviously, having a list of selected texts and a set of activities is a must. However, if a book does not enjoy popularity among students or if some event kindles the students' interest in a particular text, there is no need at all to stick to the plan.

If the teacher is pressed for time, a short poem at the beginning of a class may encourage students to read more. Poems by Edwin Morgan, Carol Ann Duffy or Sinead Morrissey have proved to enjoy almost unanimous popularity.

${ }^{10}$ Once, a female student quoted a popular Internet meme: "Every girl dreams of finding a Mr Darcy. Unfortunately, boys don't know who he is". Her words caused indignation among the male part of the class, after which the whole class read an extract from Pride and Prejudice and enjoyed comparing the Mr Darcy from the text with his numerous screen versions.

${ }^{11}$ For instance, the scandal around Julian Assange prompted the class at Kostroma State University to read the play by Tim Price "The Radicalisation of Bradley Manning", which is not only a piece of political writing but also a masterpiece of stage art, that is why debates about stage effects were as interesting as discussions of the play itself. 


\section{The New Challenge: Functional Illiteracy}

While computerisation and IT influence our lives more and more, there is an urgent need to develop the skill of transliteracy, i.e. the ability to switch from one semiotic code to another and combine information received from a variety of sources. Our observations show that students (even at an upper-intermediate level and with good command of English) are often unable to demonstrate this skill. Moreover, more and more often they show signs of functional illiteracy. Functional illiteracy may manifest itself in various ways, but to us, the most relevant (and alarming!) sign is the inability to understand the explicit and implicit meanings of a written text, although the meaning of all the words is clear. Students have been showing the inability to identify the main idea, highlight the keywords, compare and contrast, summarize the text, extract the most important information etc. It is true not only for literary texts but for Web-content, newspaper articles etc. The problem is not directly connected with the language of the text, although it seems worse when students have to use several languages in a short period. The lack of the mentioned skills stands out most obviously, as students start working on their graduation papers. To develop those specific skills the techniques applied in class should be aligned to meet these needs. In the meanwhile, the role of teachers, their level of knowledge and commitment can hardly be overestimated.

Although the problem of functional illiteracy has been studied for some time, researchers differ as to its causes. Sokolgorodskaya (2018) sees it in advertising agencies and copywriters who simplify Web texts to make them extremely easy to perceive. As a result, people 'unlearn' to read complex texts and find it challenging to understand them. The increased use of emoticons is seen by many researchers as an additional threat to literacy. A similar point of view is expressed by Tarasova (2012) who sees the problem in the "de-metaphorisation" of contemporary texts. Simple small texts, stripped of metaphoric language, are primitive, and readers soon lose the ability to decode complex texts.

There is also an opinion that small screens prevent readers from seeing large chunks of the text and result in the fragmented perception of the information.

Admitting the problem, researchers have not found a universal solution. Nienkemper (2015) advocated an individual approach to every learner, which is hardly possible in our situation. Przybylska (2017) stresses the importance of the change in the social and educational 
policies, which may be reasonable, but does not solve the problem of a particular class in a short time span ${ }^{12}$.

Thus, a useful technique to make students see between the lines is translation. The use of translation in an EFL classroom, once forgotten and ignored, is seen by many scholars as a useful tool (Atkinson, 1987, Cook, 2007, Hall \&Cook, 2012 and others). The use of translation tasks in monolingual L1 classes is widely encouraged even despite the limitations of the method (Al-Amri, 2014, Topolska Pado, 2010) .

Translation serves to help students see subtler shades of meaning. One of the effective techniques is introducing a word arranged in a synonymic chain by giving the equivalent of each word in the chain in the native tongue. In this way, students grasp the stylistic differences between the synonyms and become more aware whether synonyms can be used interchangeably or not.

The choice of extracts for translation should follow the same algorithm as the choice of reading texts. We recommend to start with passages based on action. In this case, the student can easily visualise the situation, which is extremely useful when looking for the right equivalent. Later the teacher may select more complex passages (e.g. including allusions, emotionally coloured words etc.) and pass over to texts with implicit meanings.

Translation helps to not only study the text more thoroughly but also enrich the L1 vocabulary. Students who have difficulties with understanding texts in L2 usually demonstrate a poorer command of their native language in comparison with their functionally literate peers. It is observed at all stages of education.

It should be made clear that translation tasks do not imply the translation of the whole text or the necessity to look up every unknown word in the dictionary. Teachers should not regard translation as a sole method of understanding the whole short story. That is why the passage for translation should not exceed 20-35 lines at first. Translation tasks should not cause a negative reaction that often results from students' school experience. We have witnessed situations when schoolteachers set a task of reading and translating a 5-7 page story as homework for 11-12-year-old students. Such tasks can discourage students from reading forever.

Using translation tasks with future teachers can have bonuses:

\footnotetext{
${ }^{12}$ In Australia, for instance, the government has taken practical steps to help school teachers by designing a toolkit aimed to combat functional illiteracy.
} 
1. Students will understand how to integrate translation tasks into their lessons in the future;

2. Students will have a more conscious approach to using dictionaries and reference books;

3. Students will understand the limitations of automatic translation systems such as Google Translate, Yandex Dictionary or Context Reverso. This is especially important in the context of functional illiteracy. Unable to understand a text, students upload it into Google Translate and perceive the final product as perfect, because their limited linguistic abilities prevent them from seeing numerous stylistic, semantic and grammar imperfections.

4. Students learn subtler shades of meaning in both L1 and L2, which enables them to expand their vocabulary and see stylistic differences between words. This is another serious problem among young people - they often fail to see why a word (be it in L1 or L2) does not fit the context. Often, they use bookish words to seem "cleverer", or slang in their research papers only because they are not aware of the existence of a proper word or are unable to see stylistic differences.

However, adult students aspiring to be language teachers do not fall into the traditional categories of learners struggling with reading problems. Besides, the teaching staff does not have enough time to work on the problem every day. One of the possible solutions would be to integrate literacy improving techniques into reading classes.

Several techniques have proved to be useful to make students interested in the process of reading and rid them of the feeling of disorientation in the text. For this purpose, simpler texts, e.g. detective stories, will be an excellent start, although the choice is by no means limited by this genre.

Visualization is a powerful tool for reading. It enables students to understand the setting of the story. For instance, students can draw a diagram of what the room looked like before the crime, where the guests were when the murder took place, how the position of the objects changed etc. based on the visual evidence, learners can predict "who did it". Visualisation can be used with more complicated texts (from both the language point of view and the plot). ${ }^{13}$

${ }^{13}$ For example, before discussing the story by $\mathrm{H}$. Mantel The Assassination of Margaret Thatcher we asked students to Google (and bring to class) pictures of neighbourhoods similar to the one described by Mantel. The activity helps understand not only the setting of the story but also the social status of the characters. 
Students are inclined to believe, however, that the more complex texts they will read, the more difficult it will be to understand the implicit meaning. The defeatist attitude can be overcome if the teacher supplies students with guidelines to decode the hidden meanings. These guidelines do not exist separately - they are recurrent symbols and images that permeate all forms of art. That is why helping to build associations with other art forms or life events becomes especially important. Students should be prompted to recall or find out, for instance, how spring is shown by other writers or painters, what spring symbolises (e.g., Birth, new life, revival, and resurrection). If the author uses colour-related words, students may be encouraged to study meanings of particular colours and their interpretation by a particular writer (e.g., the saffron and green imagery used by Salman Rushdie's Midnight's Children). The differences between cultures in colour perception may be another research topic.

In other words, the teacher should establish connections between universal symbols, other texts and the text under study to make students understand that texts do not exist separately, but are part of the literary corpus and that plots and themes have been recurrent for centuries.

Speaking about non-standard vocabulary, it is essential to mention that not sufficient attention is given to literature as a means of enriching students' knowledge in dialects. Conditioned by cultural, political, social, economic and other factors teaching of dialects can contribute to the development of a set of skills important, first of all, in terms of raising cultural awareness as dialectisms like nothing else are the reflection of national mentality. Let us make it clear that by dialects we mean not only the regional varieties of English worldwide but also the dialects spoken across the British Isles. Not random are the cases when people with even advanced knowledge of English experience culture shock when appear in different regions of Britain or meet native speakers from different regions. Students find great difficulty in understanding the natives because of the speed, accent, intonation, specific contractions etc. Learning dialects is not only about enriching vocabulary, which itself is an important outcome. In our estimation, the study of dialects can help learners better understand the functioning and spheres of use of Standard English. It is important for students to understand that what is called Standard language is not static and that words from one stratum can penetrate into the other. As opposed to the Standard language, dialectisms are known as units with inherent stylistic coloring. As such, they are often found in literature as a means of character building to show the social class and the level of education 
of a character or create a certain atmosphere. In such cases the limitedness of the use of the Standard language becomes evident. Teaching and practicing dialect-specific sounds and intonations can help develop such critical thinking skills as analyzing, synthesizing, connecting, integrating, etc; it may develop concentration and perceptive powers in trying to recognize dialectisms in the course of speech.

Classroom research adds to the development of such an understanding. Research may be based on the personality of the author, his/her style to let students know what to expect from this author. In addition, research may be aimed to compare events of the book with real events on which the plot is based ${ }^{14}$.

\section{Bridging the Gap between Reading Literature and Functional Literacy}

Following the observations made so far in this chapter of the paper we will discuss some techniques that can help promote the efficiency of using literature. First, let us mention that we both accentuate the need to promote extensive cultural knowledge; hence, we assume that English and American literature should not be the sole source of teaching literature. Having the experience of incorporating contemporary Scottish literature in class, we will briefly discuss what makes Scottish literature an ideal material for EFL. First, Scottish literature can be a unique source for learning Scots and extending vocabulary in dialectal words, practice some sounds which are typical of the dialect, get some elementary knowledge of Scots grammar. Many contemporary writers (James Kelman, J. Robertson, A.I. Kennedy, C.A. Duffy, J. Kay, L. Lockhead, etc) are extensively using Scotticisms and the inclusion of their works can serve the purpose. Second, Contemporary Scottish literature touches upon a range of social problems that are not limited to Scottish society. The issues of identity, crisis, polarization, alienation as well as gender-related issues are only several among the large set of issues that are widely covered in the literature. Another aspect is that contemporary literature immediately reflectsa wide range

\footnotetext{
${ }^{14}$ For instance, the play The Radicalisation of Bradley Manning, mentioned earlier, will prompt students to find information about the war in Iraq, BradleyChelsea's life, hacktivism and the Greek choir that plays an important part in the play although the play is contemporary. The element of Greek drama in a contemporary text is a proof that a text is never isolated, it is "a dwarf on the shoulders of giants", and the teacher's task is to make students see the parallels.
} 
of societal, political and economic challenges that are largely covered by press and social media, which makes it possible to combine different types of texts. Thus, a piece of literature may promote classroom discussion on up-to-date issues and urge students to carry out their research on topical issues.

We suggest incorporating literature in three stages: prereading, reading and post-reading ${ }^{15}$.

Pre-reading stage:

a) a small introductory part delivered by the teacher, concentrating both on the biography of the author and the main themes of her works;

b) a list of key words (cinema, hat, blood, knife, etc) is distributed to students. They are asked to comment on the words, find associations between them and guess the content of the text. Students may be asked to categorize the keywords, put down positive and negative associations that accompany the words;

c) after students are asked to read the title of the story, comment on it, find links between the title and keywords and after, guess what the text will be about;

d) a group of students can be asked to make the visual plan of the story which will later be compared with the original plot.

\section{Reading stage:}

a) students are asked to read the text by analyzing the vocabulary and spotting the dialectisms;

b) with the help of teacher they spot and discuss the cases of specific grammar and stylistic devices;

c) students are asked to spot the key words and discuss their role in the passage and expand on in what ways the words correlate with the passage and the story.

Post-reading stage:

This stage is crucial as it provides ample room for student talk.

Students are asked to:

a) expand on the basic idea of the text correlating the latter with the key words; discuss the conflict around which the plot develops;

b) portray the characters based on the dialogues and descriptions, recall the prototype in other novels and films, by comparing and contrasting with the characters they know;

c) detail in what ways the characters, their feelings and actions can be fitted within the concepts of loneliness and human estrangement, the major themes of A.L. Kennedy's fiction.

\footnotetext{
${ }^{15}$ The stages are described based on the story What Becomes by A. L. Kennedy (2009).
} 
d) study the theme of alienation, find information about the authors who touch upon the theme, bring examples of alienated characters and compare and contrast them with Kennedy's characters;

e) look through a bunch of photos of random people and comment which of them could be suitable for the characters, by establishing associations between the text and real people.

f) expand on the storyline by distinguishing the primary and secondary information, detail the primary information, discuss what parts could be omitted from the text and in what ways the omissions could influence the ending; think of a different ending for the story by reasoning the choice;

g) visualize and detail the places and find associations with real places;

h) summarize the text and retell from their perspective or write an essay on the theme of the story.

The activities for each stage may vary and can be further extended. However, we assume that in case three stages are in place the learning of the vocabulary and memorizing words will be an accompanying benefit and not the only goal of reading literary text.

Scottish drama can also be considered a valuable means of developing certain skills, enlarge one's knowledge in history, politics, etc. For instance, passages from Black Watch (Gregory Burke), Mary Queen of Scots Got Her Head Chopped off (Liz Lochhead), the Cheviot, the Stagg and the Black, Black Oil (John McGrath) can be considered for use. Role-play, watching the stage or screen adaptations, comparing and analyzing the characters can be an extra incentive for students to reveal new information about history, social, political, and cultural life of the country. These works can be assigned as additional home-reading tasks, accompanied by a list of tasks. For instance, Liz Lochhead's play can be an incentive to start research on the culture of design, food and fashion in royal families. The reading of passages from the Cheviot can be accompanied by individual research on Scottish history, specifically Highland clearances.

As far as poetry is concerned, let us mention that poetry, like drama, is almost excluded from the textbooks. While there is much evidence in favor of poetry as an instrument for teaching language to children, it still could be argued to be an effective instrument at all levels. One of the typical features of contemporary Scottish poetry is that it immediately reflects societal challenges. Poets freely react to what is happening in the country and thus voice their opinion through poetry, which now due to digitization becomes immediately available on social media, triggering wide discussions and shaping opinions. Scottish poetry explores spiritual and ecological themes, landscapes, urban 
spaces; poets frequently reflect on the issues of identity, self-analysis, and the status of Scots by advocating its use in literature. Poetry may serve as a means to promote knowledge in dialects are acquainted with the landmarks, national symbols and people's attitudes to them. Political poetry is one of the widely practiced genres across the UK. Poetry pieces can be combined with such activities as reading newspaper or discussing politics of the country, thus staying in tune with developments. A list of recommended authors includes Liz Lochhead, C.A. Duffy, Kathleen Jamie, Jackie Kay, Christine De Luca, Don Paterson, Edwin Morgan and many others.

\section{Conclusion}

Literature has traditionally been used in foreign language teaching contexts. Based on our observations, however, in the last decade due to objective reason the literary content is no longer predominant in language teaching syllabi at language departments in higher education of both Russia and Armenia. The simplification of the material has brought to a widespread demonstration of functional illiteracy, which in language teaching context is observed in students' failure to switch from one semiotic code to another, to analyze and synthesize pieces of information, etc. On the way of transformation to research-based education at universities development of transliteracy skills is an urgent issue that requires a revision of teaching content and approaches. As far as literature is concerned, we may safely conclude that the wellorganized lesson plans and combination of approaches and techniques can increase the knowledge in language, boost comprehension, creativity and critical thinking skills. As regards the content, the paper substantiates the importance of contemporary literature and highlights the need for cultural diversity. In this light, the paper highlighted the appropriateness of the Scottish literature for inclusion in the syllabus. Ultimately, we can conclude that the incorporation of appropriate literary materials combined with targeted techniques can encourage students to undertake individual research in this way gradually acquiring and mastering research skills. 


\section{References}

Ainy, S. "Use of literature in developing learner's speaking skills in Bangladeshi EFL contexts." University of Nottingham. (2007).

Atkinson, D. "The mother tongue in the classroom: A neglected resource?" ELT Journal 41.4, (1987): 241-247

Al-Amri, W. B. and Hussein A. "Translation in teaching and learning a foreign language: A methodological approach." International journal of humanities and social sciences 1 (2016): 24-42.

Bloemert, J. et al. "Exploring EFL literature approaches in Dutch secondary education." Language, Culture and Curriculum 29 (2016): 169 - 188.

Carter R., Long, M. N. Teaching Literature. Harlow, Essex: Longman Group United Kingdom. (1991).

Cook, G. A thing of the future: Translation in language learning. International Journal of Applied Linguistics 17.3, (2007): 396-401.

Gilroy, M. and Parkinson B. "Teaching literature in a foreign language." Language Teaching 29 (1996): 213-225.

Hall, G. and Cook, G. "Own-Language Use in Language Teaching and Learning". Language Teaching. 45 (3), (2012): 271-308

Inan, B. and Yuksel, D. "Literature and language teaching a course book." Pegem Atıf İndeksi. (2017).

Kennedy, P. and Peter Faley. "Learning Language Through Literature in Secondary Schools: A Resource Book for Teachers of English." (1999).

Maley, A. "The Cambridge Guide to Teaching English to Speakers of Other Languages: Literature in the language classroom." Cambridge University Press. (2001).

Nienkemper, B. "Lernstandsdiagnostik bei funktionalem Analphabetismus. Akzeptanz und Handlungsstrategien." (2015).

Przybylska, E. "The Phenomenon of Functional Illiteracy in the Light of Empirical Studies." (2018).

Savvidou C. An Integrated Approach to Teaching Literature in the EFL Classroom. The Internet TESL Journal (2004) Vol. 10: pp.1-6.

Topolska-Pado, J. "Use of L1 and translation in the EFL classroom." Zeszyty Glottodydaktyczne Wydawnictwo Uniwersytetu Jagiellońskiego. (2010): 11-25.

Бекишева Т.Г., Гаспарян Г.А. «Использование домашнего чтения студентов вне языковых вузах как вида самостоятельной работы» [The Use of Home Reading as a Type of Students' Self-Guided Work in Non-Linguistic Higher Education Establishments]. Philological Sciences. Theoretical and Practical Issues.no 6. (2014):27-29.

Загрядская Н. А. "Возможности использования художественных текстов на занятиях по английскому языку в неязыковом вузе (на примере направления "психология")". [Possible Uses of Literary Texts in EL classes of a Non-Linguistic University (specialization; Psychology)]. Мир науки, культуры, образования, no. 2 (63), 2017: 21--23.

Жувикина Н. Н., and Феоктистова И. В. "Интерпретация художественного текста как средство совершенствования коммуникативной 
компетенции студентов старших курсов языкового вуза" [Interpretation of Fiction Texts as a Means of Improving Communication Competence in Senior Students of Language Colleges] Царскосельские чтения, vol. I, no. XV, 2011: 317-321.

Калафато Р. Художественная литература в обучении английскому языку в России [Fiction in Teaching English in Russia] Вопросы образования, no 2, 2018: 91-116.

Соколгородская Л. Функциональная неграмотность [Functional illiteracy].: http://rusclass-khv.ru/2018/04/30/April 30, 2018. Web/ Date of access: September 28, 2020.

Тарасова О. И. "Феномен метафоры и развитие функциональной неграмотности молодежи: точки возможного пересечения" The phenomenon of metaphor and functional illiteracy development in young people: possible crossing points]. Вестник Костромского государственного университета. Серия: Педагогика. Психология. Сочиокинетика, vol. 18, no. 1-1, 2012: 203-211.

\section{ПЕРЕОСМЫСЛЕНИЕ РОЛИ ХУДОЖЕСТВЕННОЙ ЛИТЕРАТУРЫ В ПРЕПОДАВАНИИ АНГЛИЙСКОГО ЯЗЫКА В ВЫСШЕЙ ШКОЛЕ РОССИИ И АРМЕНИИ}

Целью работы является освещение роли литературы в преподавании английского языка как иностранного. Интерес к этой теме вызван растущей необходимостью изменить содержание и подходы к изучению английского как иностранного для студентов вузовских специальностей, готовящих специалистов в области преподавания иностранных языков, филологии и лингвистики. Включение литературы в рабочие программы языковых дисциплин, тщательный отбор материала и средств обучения могут помочь студентам в овладении иностранным языком и культурными компетенциями. Также в работе рассматривается использование литературы на занятиях по иностранному языку в качестве средства повышения функциональной грамотности. Перевод и визуализация художественного текста рассматриваются как эффективные средства преодоления чувство потерянности в тексте, которое испытывают многие студенты. Для повышения эффективности использования литературных произведений в классе авторы предлагают использование ряда подходов к организации работы с текстом. Обсуждение результатов и наши наблюдения могут помочь всем, перед кем стоит проблема включения литературных текстов в программу или проблема адаптации существующих методов к потребностям обучающихся.

Ключевые слова: обучение иностранным языкам, программа дисциплины, литература на уроке иностранного языка, английская литература, шотландская литература, функциональная неграмотность. 